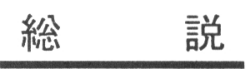

\title{
オリゴ糖鎖の機器分析
}

中島佑

東北大学農学部農芸化学科（于981 仙台市青葉区堤通雨宮町 1-1)

\section{Instrumental Analysis of Oligosaccharides}

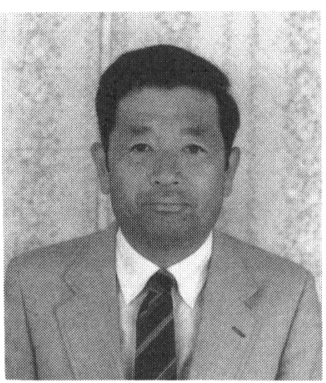

Tasuku NAKAJIMA

Department of Agricultural Chemistry, Tohoku University

(1-1, Tsutsumidori-Amamiyamachi, Aoba-ku, Sendai-shi, T981)

Recent developments of the instrumental analysis of oligosaccharides were reviewed. The methods involved (1) microanalysis of oligosaccharides by HPLC, (2) sequence analysis by a combination of exoglycosidase and HPLC, and (3) structural characterization by ${ }^{1} \mathrm{H}-\mathrm{NMR}$.

\section{はじめに}

複合糖質, 特に糖タンパク質及び糖脂質の糖鎖は細胞 表面の識別之深くかかわっており，糖鎖構造の解明は細 胞の認識機棈至明らかにするうえで重要な研究課題上 なっている。糖タンパク質あるいは糖脂質を構成する糖 鎖はオリゴ糖之よばれる重合度 2 から 20 (分子量約 180 から 3600$)$ の大きさを持つものが大部分を占めてお り, 本稿においては, これらマンノースを含むへテロオ リゴ糖の新しい分析法を紹介したい。

\section{HPLCによるオリゴ糖の微量分析}

\section{$1 \cdot 1$ HPAE-PAD 法}

最近オリゴ糖の分離に陰イオン交換樹脂とパルス電流

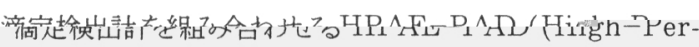
formance Anion-Exchange Chromatography with Pulsed Amperometric Detection) 法が用いられよい 結果が得られている ${ }^{1) \sim 31} 。$

HPAE-PAD 法の特徵は, 高速陰イオンクロマトグ ラフィーにより従来分離が困難であった結合位置の異な るオリゴ糖異性体が分けられること, さらに溶出条件を 変えることにより単糖から重合度約 50 の多糖に至るま できれいに分離できることである。又，パルス電流検出 計は検出感度が $10 \mathrm{pmol}$ のオーダーで, しかも糖鎖を 誘導体(例えば螢光, 放射能ラベル等) に導くことなく, 直接力ラムに供することができる点で有利である。一方, 本法で唯一の欠点をあげれば, 試料糖鎖をアルカリで溶 出するために, 試料を回収する目的には不便なことであ る。ただ，中性溶液に不溶である $\beta 1-3$ 結合, $\beta 1-4$

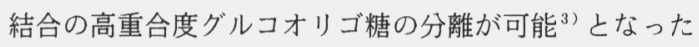

り良い点もある。

Hardy と Townsend ${ }^{1)}$ は表-1 で示した各種へテロ オリゴ糖を HPAE-PAD 法で分離した結果，用いた 16 種のオリゴ糖すべてが完全に分離されている（図一 i)。分子量の大きいオリゴ糖は一般に retention time が大きいが,これは $\mathrm{OH}$ 基の数が多ければ negative charge が増加することによると考えられる。一方，分 子量の同じ異性体同士の分離には, 糖の環状構造を構成 する炭素につく $\mathrm{OH}$ 基の酸性度が，位置により異なる $\left(\mathrm{C} 2-\mathrm{OH}>(\mathrm{C} 6-\mathrm{OH}>\mathrm{C} 3-\mathrm{OH}>\mathrm{C} 4-\mathrm{OH})^{4}\right)$ ことを利 用することができる。

HPAE-PAD 法はオリゴ糖鎖を構成する単糖の分析 にも使われる

小泉らは単純グリカンの部分加水分解物を HPAE-

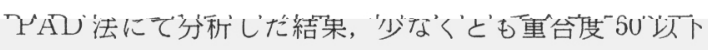

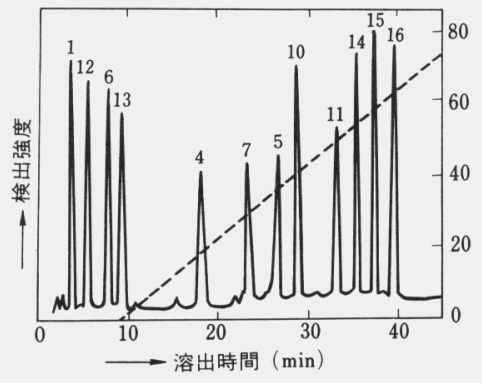

[試料]オリゴ糖混合物(表-1に示した), 各 $1 \mathrm{nmol}$

[分離条件]カラム：Dionex Carbo Pac PA-1 $(4.6 \times 250 \mathrm{~mm})$ 溶出液： $100 \mathrm{mM} \mathrm{NaOH}-100 \mathrm{mM} \mathrm{NaOH} \cdot 0.15 \mathrm{M} \mathrm{CH} \mathrm{CH}_{3} \mathrm{COONa}$, 検出：パルス電流滴定検出計

図-1 HPAE-PAD 法による中性オリゴ糖の分離〔文 献 1) より改写] 
表-1 HPAE-PAD 法にて分離された中性オリゴ糖鎖の構造

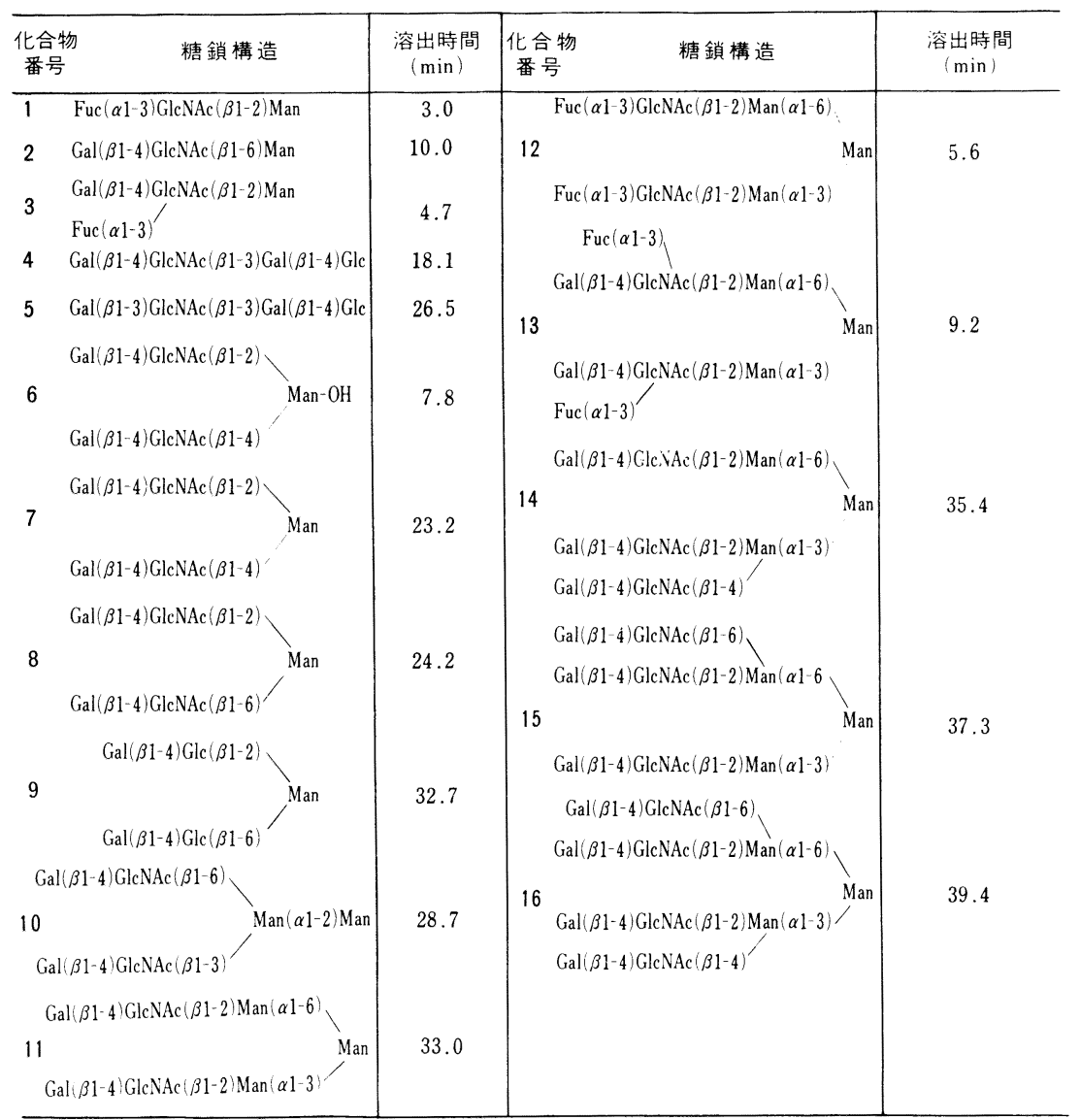

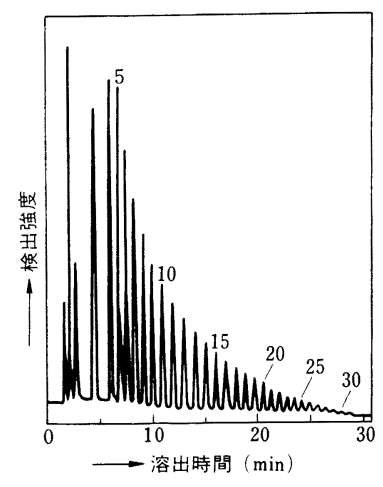

[試料] $\beta-1,3-$ グルカン (curdlan)の部分加水分解物 [分離条件]カラム: Dionex HPIC-AS6 $(4 \times 250 \mathrm{~mm})$ 溶出液: $150 \mathrm{mM} \mathrm{NaOH}-150 \mathrm{~min} \mathrm{NaOH} \cdot 0.5 \mathrm{M} \mathrm{CH} \mathrm{CH}_{3} \mathrm{COONa}$, 検出：パルス電流滴定検出計

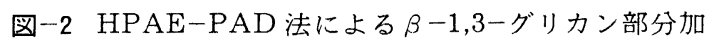
水分解物の分離 [文献 3 ) 上り改写]

であれば優れた分離パターンが得られることを示した $(\text { 図-2 })^{3)}$ 。

\section{$1 \cdot 2$ ピリジルアミノ化による蛍光標識法}

高感度検出を目的として, 糖鎖の還元末端にピリジル アミノ基の導入により蛍光標識した後, 逆相 HPLCで 分離された。単離及びオリゴ糖を蛍光検出器で分析する 方法は, 糖鎖を $0.1 \mathrm{pmol}$ という超微量で検出すること ができる ${ }^{51}$ 6)。誘導体は化学的に安定（酸やアルカリ 加水分解, ヒドラジン分解, 過ヨウ素酸々化等) で, ピ リジルアミノ化糖鎖の化学解析も可能である ${ }^{7), 8)}$ 。富 谷ら ${ }^{9)}$ は各種糖タンパク質試料からアスパラギン結合型 糖鎖を，アーモンドより調製した $N$ ーオリゴ糖一グリコ ペプチダーゼ（グリコペプチダーゼ A, 生化学工業）で 切り出した後, Bio-Gel P 4 カラムによるゲル沪過に て糖鎖部分を集め,ピリジルアミノ化した。上記蛍光標 識した誘導体を逆相力ラムとアミド結合型力ラムの併用 で，113 種の糖鎖の分離に成功した。彼らはそれぞれの 糖鎖の HPLCにおける retention time を標準グル コースオリゴマーとの相対保持時間（グルコース単位で 表示) で示し (図-3), 逆相カラム (ODS-Silica) での 溶出位置をグルコース単位で表したものを横軸に，また 


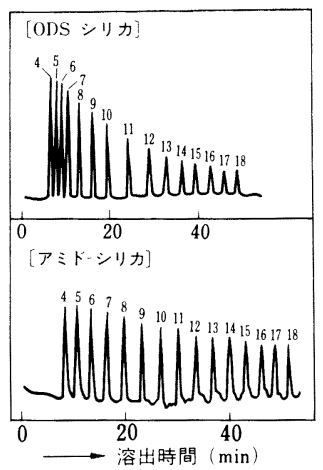

[試料]ピリジルアミノ化したデキストラン部分分解物, (図中の番号はグルコース単位を表示)。

[分離条件]第 । カラム:ODS-Silica[Shimpack CLC-ODS $(6 \times 150 \mathrm{~mm})]$, 溶出液: $(\mathrm{A}), 10 \mathrm{mM}$ リン酸ナトリウム緩衝液, $\mathrm{pH} 3.8,(\mathrm{~B}), 10 \mathrm{mM}$ リン酸ナトリウム綏衝液, 1ーブタノール, 直線濃度勾配法にて溶出, $55^{\circ} \mathrm{C}$

第 2 カラム: Amide-Silica[TSK GEL Amide-80[4.6× $250 \mathrm{~mm})]$, 溶出液: (A), $3 \%$ 酢酸を含むトリメチルアミン, $\mathrm{pH} 7.3$ 一アセトニトリル, $35: 65$, (B)，3\%酢酸を含むトリメ チルアミン, $\mathrm{pH} 7.3$ 一アセトニトリル, $50: 50$, 直線濃度勾 配法にて溶出, $40^{\circ} \mathrm{C}$ 。

検出: 常光検出計, 励起波長 $320 \mathrm{~nm}$, 虽光波長 $400 \mathrm{~nm}$

図-3 蛍光法によるピリジルアミノ化グルコオリゴ糖 の分離〔文献 9)より改写〕

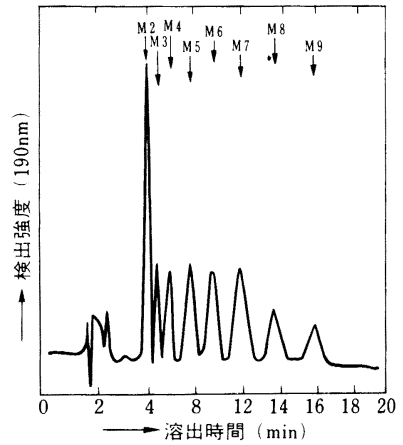

[試料]マンノシドーシス患者尿中のオリゴ糖, 図中の番号, $\mathrm{M} 2: \mathrm{Man}_{2} \mathrm{GlcNAc}, \mathrm{M} 3: \mathrm{Man} 3 \mathrm{GlcNAc}$, 以下マンノース残基の 数を表す。

[分離条件]カラム:Amide - Silica[MicroPak NH $300 \mathrm{~mm})]$ ，溶出液: アセトニトリル一水, $55: 45$ から $51: 49$ まで 段階的に混合比を変化させる。 $26^{\circ} \mathrm{C}$

検出: 紫外吸收検出器。

図-4 高マンノース型オリゴ糖のアミン結合型シリカ カラムによる分離〔文献 10)より改写〕

アミドーシリカカラムでの溶出位置を縦軸によって, 113 種のアスパラギン結合糖鎖の二次元マップを作成 し, 未知オリゴ糖の HPLC の溶出位置をマッピングす ることで構造推定が可能なことを示した。

\section{$1 \cdot 3$ その他の方法}

オリゴ糖試料が nmol 以上むる場合は，前述の方法 によらなくても示差屈折検出計 (RI detector) を用いて 試料を誘導体とせずに直接分析する方法が簡単でよい。

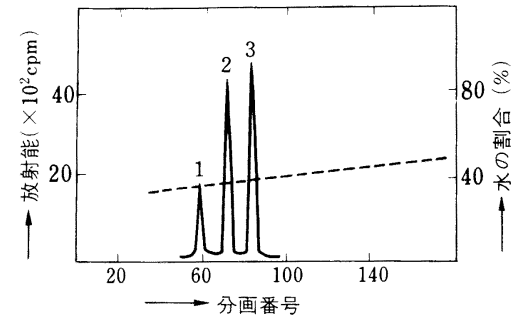

[試料]卵白アルブミン糖ぺプチドをエンドー $\beta-N-ア セ ~$ チルグルコサミニダーゼーHで処理して得たオリゴ糖鎖を $\mathrm{NaB}^{3} \mathrm{H}_{4}$ で還元したもの。1:Man $\mathrm{GlcNAc}^{-} \mathrm{O}^{3} \mathrm{H}, 2:$ Man6 $\mathrm{GlcNAc}^{-} \mathrm{O}^{3} \mathrm{H}, 3: \mathrm{Man}_{7} \mathrm{GlcNAc}^{-} \mathrm{O}^{3} \mathrm{H}$

[分離条件]カラム：アミン結合型カラム( $\mu$-Bondapak

Carbohydrate $(4 \times 300 \mathrm{~mm})$, 溶出液：アセトニトリル一水 $(65: 35)$, 水の割合を变化させる。

検出：シンチレーションカウンター

図-5 ${ }^{3} \mathrm{H}$ 標識した卵白アルブミン糖鎖の分離〔文献 11) 上り改写]

特に調製を目的とするのであれば RI 法で行う方が後の 分析のために好ましい。Warren ら ${ }^{10)}$ はマンノシドー シス患者の尿中の高マンノース型オリゴ糖をアミン結合 型シリカカラムとUV 検出器を用いて分析した（図一 4)。通常本カラムのオリゴ糖分離にはアセトニトリルー 水系が溶媒として用いられ，糖の残基数と溶出時間には 直線関係が成りたつ。

糖鎖の還元末端を $\mathrm{NaB}^{3} \mathrm{H}_{4}$ で還元し，トリチウム標 識したのち HPLC で分離, シンチレーションカウン ターで検出する方法は, 理論的には超微量分析も可能で ある。

Merris, Boenzinger ${ }^{11)}$ は卵白アルブミン糖鎖を $\mathrm{NaB}^{3} \mathrm{H}_{4}$ で還元し，アミン結合型シリカカラムを用い て分析した (図一)。

\section{2 オリゴ糖鎖の構造解析}

\section{$2 \cdot 1$ 糖鎖構造解析の手順}

オリゴ糖鎖解析の内容を要約すると 1) 単糖組成の分 析, 2) 糖残基の配列順の決定，3）糖残基の結合位置の 決定，4）糖残基のアノマー型分析，の 4 点になる。才 リゴ糖の構造解析法は, メチル化分析法, 酸あるいは酵 素による完全加水分解ならびに部分加水分解法, 過ヨウ 素酸々化法等, 従来の方法は糖鎖の分解を伴うのに対し, 最近は分析機器 (NMR, MS, HPLC 等) の発展に伴っ て, 精製試料があれば直接分析可能な方法に変わりつつ ある。

\section{$2 \cdot 2$ 単離組成の分析}

オリゴ糖を酸あるいは酵素で完全加水分解した後, HPLC あるいはGLCにて単糖組成を分析する。HPLC による方法は HPAE-PAD 法 (図-6 $)^{2)}$ ピリジルアミ 八誘導体による蛍光分析法 ${ }^{12)}$, 卜リチウム標識法 ${ }^{13)}$ 等 の微量分析法から, 示差屈折計を使用する一般的方法が 
ある。

単糖組成分析はGLCによる方法も HPLC 法に劣ら ず優れており，使用例が多い。GLCにより糖を分析す る場合は誘導体にする必要があり, アルジトールアセ テート誘導体による方法 (図一7 ${ }^{14}$ ), トリフルオロアセ チル (TFA) 誘導体による方法 ${ }^{15)}$, トリメチルシリル 誘導体による方法 ${ }^{16)}$ が一般的で, よ゙の方法もよい結果 が得られる。

\section{$2 \cdot 3$ 酵素法による糖残基の配列決定よアノマー分析}

糖残基の配列順序を決めるには, 通常エキソグリコシ ダーゼによる逐次分解の過程を HPLCで分析する。長 谷ら は Barbados pride 種子より得た糖タンパク, プロテアーゼインヒビターの糖鎖構造研究において, 糖 残基の配列とアノマー型を各種エキソグリコシダーゼに よる逐次分解法で決定した（図一8）。逐次分解産物の分 析はHPLCによらなくとも, ゲル沪過法 (Bio-Gel P 2 あるいは P 4), 沪紙クロマトグラフィー, 高圧沪紙電 気泳動法等で行うことができる。

\section{$2 \cdot 4$ 質量分析法による糖鎖の分子量, 糖残基の配列}

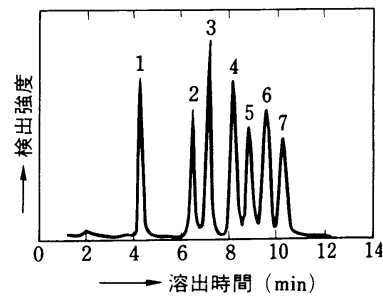

[試料] $1:$ Fuc, $2: 2$-deoxyGlc, $3:$ GalN, $4: \mathrm{GlcN}, 5: \mathrm{Gal}, 6: \mathrm{Glc}, 7: \mathrm{Man}$ 各種2.5nmol。 [分離条件]カラム:陰イオン交換樹脂[Dionex Carbopac AS $-6(4.6 \times 250 \mathrm{~mm})]$ 。溶出液: $22 \mathrm{mM}$ $\mathrm{NaOH}$ 検出:パルス奄流滴定検出計。

図一6 HPAE-PAD 法による単糖の分離〔文献 2) よ り改写]

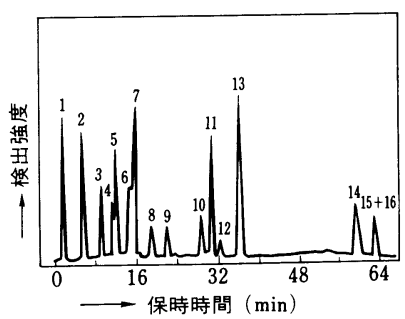

[試料] $1:$ Glycerol, $2:$ Erythrose, $3: 2$-deoxy Rib., 4 :Rham, $5:$ Fuc, $6:$ Ara, $7:$ Rib, $8:$ Xyl, $9: 2$-deoxyGlc, $10:$ Man, 11:Gal, 12:Glc, 13:Inositol, 14 : GlcNAc, 15 : GalNAc, 16 : ManNAc. [分離条件]カラム: $0.2 \% \mathrm{EGS}-0.2 \% \mathrm{EGA}-1.4 \%$ シリコンXE-60, 担体 (GaschromP, 100 200mesh) 温度 : $150^{\circ} \mathrm{C}$ から $205^{\circ} \mathrm{C}$ まで $1{ }^{\circ} \mathrm{C} / \mathrm{min}$ ·昇温

図-7 単糖アルジトールアセテートの GLC による分離 〔文献 14)より改写〕

\section{順の決定}

FAB (Fast Atom Bombardment) 法, SI (Secondary Ion) 法は EI (Electron Ionization) 法と比較し て，オリゴ糖のような極性が高く，分子量が大きく，熱 分解しやすい試料でも誘導体とせずに分子イオンピーク $\left[(\mathrm{M}+\mathrm{H})^{+}\right.$や $(\mathrm{M}+\mathrm{H})^{-}$等

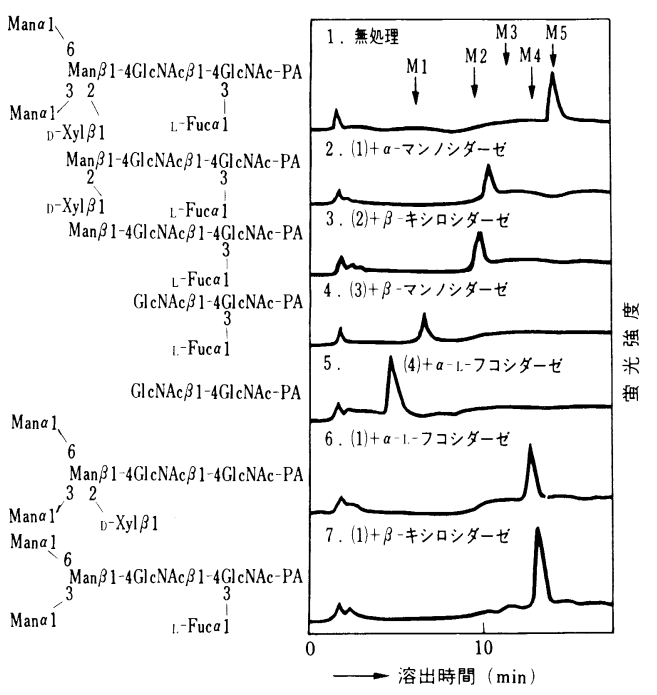

分子量マーカー, M 5 : Man $5 \mathrm{GlcNAc}_{2}$ - PA, M4,M3, も同様に

Man残基（へキンース）の数を表す。

方法:ピリジルアミノ化したオリゴ糖の各種エキソグリコシタ

一ゼによる逐次分解産物をHPLC法で分析した。

カラム: MicroPak AX-5 $(4.6 \times 150 \mathrm{~mm})$.

図一8 ヘテロオリゴ糖の各種グリコシダーゼによる逐 次分解〔文献 7) 上り改写〕

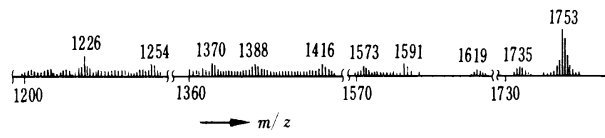

\begin{tabular}{lrl}
\hline$m / z$ & 相対強度 $(\%)$ & \multicolumn{1}{c}{ イオン組成 } \\
\hline 1753 & 100 & $\mathrm{M}-\mathrm{H}$ \\
1735 & 18 & $1753-\mathrm{H}_{2} 0$ \\
1619 & 8 & $\left(\mathrm{~S}_{6}+\mathrm{HCO}\right)-\mathrm{H} /\left(\mathrm{S}_{6^{\prime}}+\mathrm{HCO}\right)-\mathrm{H}$ \\
1591 & 24 & $\left(\mathrm{~S}_{6}+\mathrm{H}\right)-\mathrm{H} /\left(\mathrm{S}_{6^{\prime}}+\mathrm{H}\right)-\mathrm{H}$ \\
1573 & 18 & $1591-\mathrm{H}_{2} 0$ \\
1416 & 16 & $\left(\mathrm{~S}_{5}+\mathrm{HCO}\right)-\mathrm{H} /\left(\mathrm{S}_{5^{\prime}}+\mathrm{HCO}\right)-\mathrm{H}$ \\
1388 & 29 & $\left(\mathrm{~S}_{5}+\mathrm{H}\right)-\mathrm{H} /\left(\mathrm{S}_{5^{\prime}}+\mathrm{H}\right)-\mathrm{H}$ \\
1370 & 18 & $1388-\mathrm{H}_{2} 0$ \\
1254 & 21 & $\left(\mathrm{~S}_{4}+\mathrm{HCO}\right)-\mathrm{H} /\left(\mathrm{S}_{4^{\prime}}+\mathrm{HCO}\right)-\mathrm{H}$ \\
1226 & 45 & $\left(\mathrm{~S}_{4}+\mathrm{H}\right)-\mathrm{H} /\left(\mathrm{S}_{4^{\prime}}+\mathrm{H}\right)-\mathrm{H}$ \\
\hline
\end{tabular}

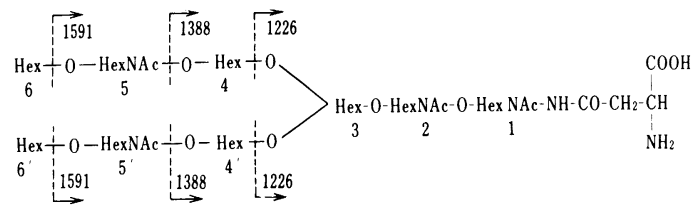

図-9 アスパラギン結合型糖鎖の負イオン FAB-MS による構造解析〔文献 22) より改写] 
きると同時にフラグメントイオンを読むことにより糖残 基の配列順が決定できる ${ }^{20) .211}$ 。Kamerling ら ${ }^{22)}$ は分 子量 1754 のアスパラギン結合型糖鎖の負イオン FABMS スペクトルをとり, 糖残基の配列順序を決定した(図 -9)。福田ら ${ }^{23)}$ (骨䯣性血液病細胞より得たラクトサ ミノグリカンと正常細胞より得た同グリカンの FABMS スペクトルを比較して, 糖鎖の異常を明らかにした。

\section{$2 \cdot 5$ オリゴ糖鎖の ${ }^{1} \mathrm{H}-\mathrm{NMR}$ (PMR) による構造解析}

高分解能 NMR (400 MHz, $500 \mathrm{MHz})$ のオリゴ糖構 造解析への応用は, 得られる情報の多さから現在ではオ リゴ糖構造決定に最も有効な手段とされている ${ }^{24)}$.25)。

${ }^{1} \mathrm{H}-\mathrm{NMR}$ から得られる情報は，1）糖残基のアノマー 型，2）構成糖残基の種類と組成比，及び 3 ) 結合様式之 配列順序を示す。また，重合度が小さいオリゴ糖鎖であ れば，糖鎖を分解することなしにNMR をとるだけで 構造の同定が可能である。Vliegenthart ら ${ }^{21,26)}$ (2, 糖夕ンパク糖鎖の ${ }^{1} \mathrm{H}-\mathrm{NMR}$ デー夕を数多く解析する ことにより, 判別しやすく, 構造解析に有効な情報を与 えるプロトン群をとり出し, “Structural reporter group”と名づけた。本分析により，1) アノメリックプ ロトン (H-1 プロトン), ケミカルシフトとカップリン グコンスタントから糖残基の種類とグリコシド結合のア ノマー型がわかる。2) マンノースの $\mathrm{H}-2$ と $\mathrm{H}-3$ プロ トン, これらシグナルのパターンから，N-アセチルグ ルコサミンに結合するマンノトリオース（コアの構造）
の分岐の構造がわかる。3) シアル酸の $\mathrm{H}-3$ プロトン, シアル酸のグリコシド結合の型及び立体配置 (configuration) がわかる。又, 構造によっては, シアル酸の糖 銷における位置も推定できる。4) フコースのH-5 とメ チルプロトン, ケミカルシフトからグリコシド結合の型 及び立体配置, そしてフコースの結合している糖残基の

(1)

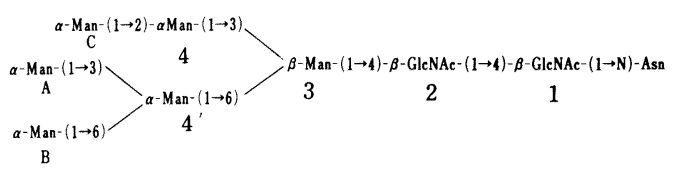

(2)

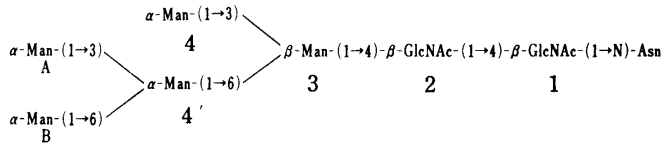

(3)

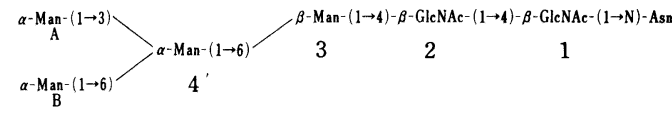

(4)

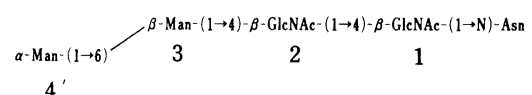

図-10 卵白アルブミン糖銷とそのマンノシダーゼ分解 物の構造 [文献 24) より改写]

表-2 卵白アルブミン糖鎖及びマンノシダーゼ分解物のプロトン-NMR, Structural reporter group の化学シフト ${ }^{24)}$ (オリゴ糖の構造は図-10 に示した。）

\begin{tabular}{|c|c|c|c|c|c|}
\hline \multirow{2}{*}{ Structural reporter group } & \multirow{2}{*}{ 糖残基番号 } & \multicolumn{4}{|c|}{ オリゴ糖鎖（図-10 参照）の化学シフト（ $\delta)$} \\
\hline & & (4) & (3) & (2) & (1) \\
\hline \multirow[t]{2}{*}{ Man-H-1 プロトン } & 1 & 5.071 & 5.069 & 5.071 & 5.070 \\
\hline & 2 & 4.618 & 4.608 & 4.606 & 4.605 \\
\hline \multirow[t]{2}{*}{ NACーメチルプロトン } & 1 & 2.014 & 2.013 & 2.012 & 2.011 \\
\hline & 2 & 2.076 & 2.061 & 2.060 & 2.061 \\
\hline \multirow[t]{6}{*}{ Man-H-1 プロトン } & 3 & 4.767 & 4.770 & 4.781 & 4.770 \\
\hline & 4 & - & - & 5.099 & 5.342 \\
\hline & $4^{\prime}$ & 4.915 & 4.870 & 4.872 & 4.871 \\
\hline & A & - & 5.076 & 5.093 & 5.095 \\
\hline & B & - & 4.909 & 4.908 & 4.908 \\
\hline & $\mathrm{C}$ & - & - & - & 5.052 \\
\hline \multirow[t]{6}{*}{ Man-H-2 プロトン } & 3 & 4.080 & 4.076 & 4.251 & 4.229 \\
\hline & 4 & - & - & 4.077 & 4.114 \\
\hline & $4^{\prime}$ & 3.968 & 4.140 & 4.144 & 4.143 \\
\hline & A & - & 4.064 & 4.066 & 4.066 \\
\hline & B & - & 3.988 & 3.985 & 3.990 \\
\hline & $\mathrm{C}$ & - & - & - & 4.066 \\
\hline
\end{tabular}


構造が推定できる。 5$)$ ガラクトースの $\mathrm{H}-3$ 及び $\mathrm{H}-4$ プロトン, ケミカルシフトからガラクトースと, そして ガラクトースに結合している糖残基の結合の型及び立体 配置がわかる。6) アミノ糖 (N-アセチルグルコサミン とシアル酸) の $N$-アセチル基のメチルプロトン，これ らのケミカルシフトは, 小さな構造変化に対しても非常 に鋭敏であり，構造解析に役に立つ多くの情報を与えて くれる。詳細はVliegenthart らの優れた総説を参照し ていただくよして，ここでは卵白アルブミン糖鎖及びマ ンノシダーゼ分解物の “Structural reporter group” のケミカルシフトを示す (図-10, 表-2 ${ }^{24)}$ 。

\section{おわりに}

この 10 年間で複合糖質由来のオリゴ糖鎖構造の研究 は分析機器(主として HPLC, ${ }^{1} \mathrm{H}$ 及び ${ }^{13} \mathrm{C}-\mathrm{NMR}, 2 \mathrm{D}$ -NMR, GC-MS, FAB-MS 等) の進歩と平行して飛 躍的に進んだ。ここで取り上げた話題はその中のほんの 一部であり，主として糖鎖の微量分析について述べた。 従って糖鎖の構造解析には常法之して使われるメチル化 分析法についてはふれていない。オリゴ糖鎖構造解析に ついてはすぐれた成書が数多く出されているので詳しく はそちらを参照されたい(26) 28)。

\section{[平成元年 (1989) 5 月 15 日受理]}

\section{文献}

1) M.R. Hardy, R.R. Townsend, Proc. Natl. Acad. Sci. USA, 85, 3289 (1988)

2) M.R. Hardy, R.R. Townsend, Y.C. Lee, Anal. Biochem., 170, 54 (1988)

3) K. Koizumi, Y. Kubota, T. Tanimoto, Y. Okada, J. Chromatogr., 464, 365 (1989)

4) J.A. Randlemen "Carbohydrates in Solution" (R.F. Gould, ed) Adv. Chem. vol.117, Am. Chem. Soc., Washigton DC, (1971) p.51

5) S. Hase, T. Ikenaka, Y. Matsushima, J. Biochem., 95, 197 (1984)

6) 長谷純宏, 化学上生物, 22, 38 (1984)

7) S. Hase, S. Koyama, H. Daiyasu, H. Takemoto, Y. Kobayashi, Y. Kyogoku, T. Ikenaka, J. Biochem., 100, 1 (1986)

8) N. Takahashi, I. Ishii, H. Ishihara, M. Mori, S.
Tejima, R. Jefferis, S. Endo, Y. Arata, Biochem., 26, 1137 (1987)

9) N. Tomiya, J. Awaya, M. Kurono, S. Endo, Y. Arata, N. Takahashi, Anal. Biochem., 171, 73 (1988)

10) C.D.Warren, A.S. Schmit, R.W. Jeanloz, Carbohydr. Res., 116, 171 (1983)

11) S.J. Merris, J.U. Boenzinger, Anal. Biochem., 114, 276 (1981)

12) H. Takemoto, S. Hase, T. Ikenaka, Anal. Biochem., 145, 245 (1985)

13) M. Takeuchi, S. Takasaki, N. Inoue, A. Kobata, J. Chromatogr., 400, 207 (1987)

14) L.J. Griggs, A. Post, E.R. White, J.A. Finkelstein, W.E. Moeckel, K. Holden, J.E. Zarembo, J.A. Weisbach, Anal. Biochem., 43, 360 (1971)

15) T. Imahari, Y. Arakawa, Z. Tamura, Chem. Pharm. Bull. (Tokyo), 17, 1967 (1969)

16) J.F. Rocca, J. Rouchousse, J. Chromatogr., 117, 216 (1976)

17) K. Yamashita, Y. Tachibane, A. Kobata, Arch. Biochem. Biophys., 182, 546 (1977)

18）中島 佑, 農化, 62, 1264 (1988)

19) T. Nakajima, C.E. Ballou, J. Biol. Chem., 249, 7685 (1974)

20) A. Dell, Adv. Carbohydr. Chem. Biochem., 45, 19 (1987)

21）飯島ら，“複合糖質研究法， II”日本生化学会編，東京 化学同人 (1986), p.157

22) J.P. Kamerling, W. Heerma, J.F.G. Vliegenthart, B.N. Green, I.A.S. Lewis, G. Strecker, G. Spik. Biomed. Mass Spectrom., 10, 420 (1983)

23) M. Fukuda, B. Bothner, P. Ramsamooj, A. Dell, P.R. Tiller, A. Varhi, J.C. Klock, J. Biol. Chem., 260, 12957 (1985)

24) J.F.G. Vliegenthart, L. Dorland, H. van Halbeek, Adv. Carbohydr. Chem. Biochem., 41, 209 (1983)

25）賀佐伸省, “複合糖質研究法, II ”日本生化学会編, 東 京化学同人 (1986), p.131

26) V. Ginsberg, "Complex Carbohydrates" in Methods in Enzymol. vol.50, (1978), vol.83 (1982), vol.138 (1987) Academic Press, New York

27）日本生化学会編, “複合糖質研究法 I 及びI”（1985） 東京化学同人

28）高橋禮子ら, “糖蛋白質糖鎖研究法”生物化学実験法, 23, (1989), 学会出版センター 